\title{
Determination of General Circulation Model Domain Using LASSO to Improve Rainfall Prediction Accuracy in West Java
}

\author{
Nanda Fadhli ${ }^{1}$, Aji Hamim Wigena ${ }^{2}$,Anik Djuraidah ${ }^{3}$ \\ \{nanda_senyo@apps.ipb.ac.id ${ }^{1}$,aji_hw@apps.ipb.ac.id ${ }^{2}$, anikdjuraidah@apps.ipb.ac.id ${ }^{3}$ \}
}

Department of Statistics, IPB University, Bogor, 16680, Indonesia, Phone/Fax (0251) $8624535^{123}$

\begin{abstract}
The Statistical downscaling technique has often been used to predict rainfall. This technique needsa domain of general circulation model (GCM) data. The selection of GCM domain is an important factor to improvepredictionaccuracy.The goal of this study is to determine the optimum domain. This study uses GCM data from CFSRv2 with gridresolution $2.5^{\circ} \times 2.5^{\circ}$ and local rainfall data in West Java. The GCM domain is determined basedon minimum correlation value of 0.3 between GCM data and local rainfall data. Correlations are calculated for the grid in the four directions of the compass with one grid as the reference that straightly above the local rainfall station. The domains are evaluated using the regression model with L1 (LASSO) regularization. The result showed that the optimum domain was $8 \times 5$ grids.
\end{abstract}

Keywords: GCM domain, statistical downscaling, LASSO regression

\section{Introduction}

West Java is faced with the risk of flooding (BMKG 2016) and drought (BMKG 2019) which destroy a thousand hectares of agricultural land. These are because of extremely high rainfall or low rainfall that faced by various societies group. Therefore, rainfall prediction information is needed.

General Circulation Model (GCM) can be used to obtain information for rainfall prediction [10]. The model produces data in the form of climate parameter values (such as precipitation) on the GCM grid. However, GCM grid resolution includes a large resolution so that precipitation on the grid cannot be used directly to describe rainfall in a local scale area with a smaller grid resolution [8].

Statistical downscaling (SDS) techniques can be used to obtain local scale information using global scale data. This technique requires a contiguous group of grids on GCM, called the GCM domain. The selection of GCM domains is an important factor in the SDS technique and will determine the prediction results [9]. Wigena (2006) used an $8 \times 8$ domain in Indramayuwhich resulted RMSEP about 63-98 and correlation about 0.50-0.76. Santri (2016) used an $8 \times 8$ domain in Indramayuwhich resulted RMSEP about 67-148 and correlation about 0.84-0.94.

This study aims to determine the optimum GCM domain in West Java. The GCM domain determination uses the concept of a minimum correlation of 0.3 (Garcia 2010) between the GCM grid data (predictor) and local rainfall data (response) for the grid located in the four 
compass directions. The relationship closeness between response and predictors is one of the requirements in the SDS technique [3]. This domain is expected to improve the accuracy of rainfall prediction.

\section{Data and Methodology}

\subsection{Data}

This study uses two types of data. The predictor variables are GCM monthly precipitation data from 1981 until 2009 (348 months). These GCM data were generated from the Climate Forecast System Reanalysis (CFSR) model and could be downloaded from the website https://rda.ucar.edu/. The resolution of GCM data is $2.5^{\circ} \times 2.5^{\circ}$ above the territory of Indonesia which located at $12^{\circ} \mathrm{N}$ to $-15^{\circ} \mathrm{S}$ latitude and $90^{\circ} \mathrm{E}$ to $150^{\circ} \mathrm{E}$ longitude. The response variable is monthly rainfall data $(\mathrm{mm})$ from 27 local rainfall stations in West Java which located at $-7.78^{\circ} \mathrm{S}$ to $-6.28^{\circ} \mathrm{S}$ latitude and $108.40^{\circ} \mathrm{E}$ to $107.87^{\circ} \mathrm{E}$ longitude. The rainfall data are from BMKG.

\subsection{Methods}

The analysis procedure used R 3.5.2 software with the following steps:

1. Preparing data

a. Transforming CFSR data from netCDF format into R dataframe using nedf4 package.

b. Merging predictor variables (CFSR data) with response variables (local rainfall data).

c. Cleaning the missing value so the data had a different length of data at each station, but in general, these data length is 348 months.

d. Splitting data into modeling data and validation data. Modeling data are the entire month's data except validation data. While the validation data are data in the last 12 months.

e. Exploring data by looking at the rainfall patterns.

2. Determining the optimum GCM domain for West Java.

a. Determining the reference GCM grid which is the closest coordinate grid to the local rainfall station.

b. Calculating the correlation value between local rainfall and GCM precipitation grid at the four compass directions.

c. Selecting grids withminimum correlation value of 0.3 .

d. Forming a square or rectangular domain that includes the grids at point (2.c). Illustration of determining the GCM domain is shown in Figure 1.

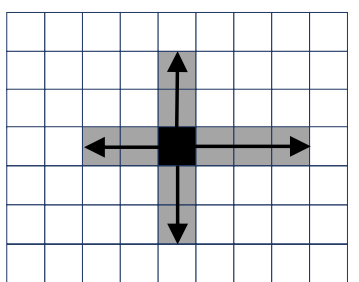

: Reference grid

: Grids that had a minimum correlation of 0.3

Fig. 1.Illustration of determining the GCM domain 
e. Modeling the domain at point (2.d) using the LASSO regression with glmnet function on the R program, and looking for minimum lambda $(\lambda)$ using the cv.glmnet function.

f. Determining the significance of grid using LASSO regression for each domain.

g. Merging all the significant grids from each domain into one large domain. If more than one grid intersects then only one grid includes in the domain.

h. Calculating the rainfall average for each type of land (such as low, medium, and plateau).

i. Calculating the correlation value between all grids in large domain and rainfall average for each type of land at point (h).

j. Selecting adjacent grids with correlation value $\geq 0.3$, so that the optimum domain is formed.

k. Performing LASSO regression using the optimum domain for each land.

1. Calculating predictions and calculate RMSEP and correlation value for validation data.

\section{Results and Discussion}

Results. Data exploration is carried out on three local stations representing each type of land. The stations are Leles station (lowland 0-200 masl), Lengkong station (medium land 200-500 masl), and Sangiang station (plateau> 500 masl)[6]. Figure 2 shows that monthly rainfall increases with increasing altitude above sea level. Marpaung (2010) also revealed that land with an altitude of 600-1300 masl has the highest annual rainfall average compared to land with altitudes below 600 masl. U-shaped rainfall patterns are following the monsoon rainfall pattern in West Java.

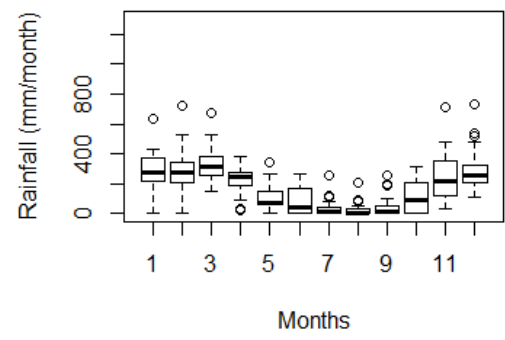

(a)

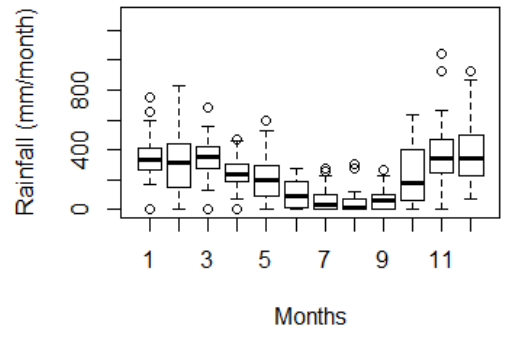

(b)

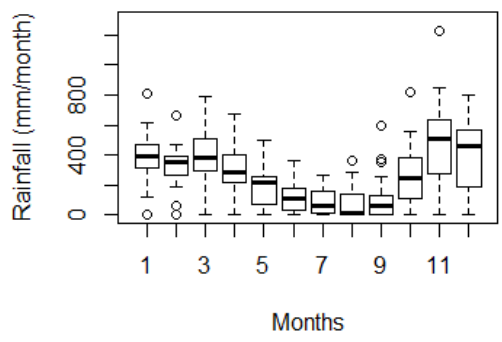

(c)

Fig. 2.Rainfall pattern of stasions: (a) Leles, (b) Lengkong, and (c) Sangiang 
The results of each land (Table 1) shows that there are 17 stations with RMSEP between 37 and 100, while 10 stations with RMSEP more than 100. There are 19 stations having correlation between 0.8 to 0.96 , and 8 stations having correlation more than 0.8 . In general these domains results in relative small RMSEPs and high correlations.

Table 1.Domain evaluation results

\begin{tabular}{|c|c|c|c|c|}
\hline \multirow[t]{2}{*}{ Land } & \multicolumn{2}{|l|}{ RMSEP } & \multicolumn{2}{|l|}{ Correlation } \\
\hline & 37 to 100 & 100 to 156 & 0.71 to 0.8 & 0.8 to 0.96 \\
\hline Low & 14 & 3 & 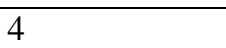 & 13 \\
\hline Medium & 0 & 4 & 2 & 2 \\
\hline Plateau & 3 & 3 & 2 & 4 \\
\hline All Stations & 17 & 10 & 8 & 19 \\
\hline
\end{tabular}

Large domains are shown in Figure 3. The domain still includes a number of insignificant grids, so the first and last rows in the domain are deleted, because more than $50 \%$ gridsare not significant. As the result, the size of large domain becomes $21 \times 5$.

\begin{tabular}{|c|c|c|c|c|c|c|c|c|c|c|c|c|c|c|c|c|c|c|c|c|c|}
\hline & 95 & 98 & 100 & 103 & 105 & 108 & 110 & 113 & 115 & 118 & 120 & 123 & 125 & 128 & 130 & 133 & 135 & 138 & 140 & 143 & 145 \\
\hline 2.5 & $\times 78$ & X79 & \begin{tabular}{|l|}
$x 80$ \\
\end{tabular} & $x 81$ & $x 82$ & $x 83$ & $x 84$ & $x 85$ & $x 86$ & $x 87$ & \begin{tabular}{|l|}
$x 88$ \\
\end{tabular} & X89 & $\times 90$ & $\times 91$ & \begin{tabular}{|l|}
$x 92$ \\
\end{tabular} & $\times 93$ & $\times 94$ & X95 & $\times 96$ & X97 & X98 \\
\hline & K103 & $\times 104$ & $\times 105$ & 106 & $\$ 107$ & 108 & 109 & $\times 110$ & 111 & 112 & X113 & 114 & X115 & & 117 & & 119 & 20 & 121 & & $\times 123$ \\
\hline-2.5 & 128 & $\times 129$ & $\times 130$ & 131 & K132 & & & & 136 & & | 138 & & 140 & & 142 & 143 & 144 & 45 & 146 & & 1 \\
\hline & 153 & X154 & \begin{tabular}{|l|}
$x 155$ \\
\end{tabular} & $\times 156$ & X157 & 158 & & & 161 & & X163 & $\times 164$ & $\times 165$ & 166 & $\times 167$ & $\times 168$ & $\times 169$ & 70 & $\times 171$ & 172 & $\{173$ \\
\hline-7.5 & 178 & $\times 179$ & X180 & $\times 181$ & X182 & $\times 183$ & X184 & $\times 185$ & 186 & $\times 187$ & $\times 188$ & $\times 189$ & $\times 190$ & X191 & $\times 192$ & $\times 193$ & $\times 194$ & 195 & $\times 196$ & $\times 197$ & K198 \\
\hline-10 & $\times 20$ & $\times 204$ & $\times 209$ & $\times 206$ & $x 207$ & $\times 208$ & $\times 205$ & $\times 210$ & $x 211$ & $\times 212$ & $\times 213$ & $\times 214$ & $\times 215$ & $x 216$ & $\times 217$ & $\times 218$ & X219 & $\times 220$ & $x 221$ & $x 222$ & $\times 223$ \\
\hline-13 & $\times 228$ & $\times 22$ & $\times 230$ & $\times 231$ & $\times 232$ & $\times 233$ & $\times 234$ & $\times 235$ & $\times 236$ & $\times 237$ & $\times 238$ & $\times 239$ & $\times 240$ & $\sqrt{x} \times 241$ & $x 242$ & $\times 243$ & X244 & $\times 245$ & $\times 246$ & $\times 247$ & $\times 248$ \\
\hline-15 & $\times 25$ & $\times 254$ & X259 & $\times 256$ & $\times 25$ & $\times 258$ & $x 259$ & $\times 260$ & X261 & $\times 262$ & $\times 269$ & $1 \times 264$ & X265 & $8 \times 266$ & X267 & $\times 268$ & $\times 26$ & $\times 270$ & $\times 27$ & $x 272$ & $\times 273$ \\
\hline
\end{tabular}

Fig. 3.Large Domain

Furthermore, the $21 \times 5$ domain is optimized to examine the relationship closeness between the predictor and response variables. This relationship is based on the correlation of the predictors in the domain grids and the response variables of each type of land. The optimum domain consists of grids with the correlation value> 0.3 and adjacent each other. Based on these criteria, the optimum domain size is $8 \times 5$.

The optimum domain is evaluated based on the values of RMSEP and correlation resulted from LASSO regression modeling. Table 2 shows that RMSEP in each land is relatively small and the correlation is relatively large. The result show that the domain size of $8 \times 5$ with grid size of $2.5^{\circ} \times 2.5^{\circ}$ is optimum. The optimum domain for West Java is shown in Figure 4.

Table 2.RMSEP and Correlation in Each Land

\begin{tabular}{llll}
\hline Land & Domain & RMSEP & Correlation \\
\hline Low & $8 \times 5$ & 23.61 & 0.99 \\
Medium & $8 \times 5$ & 75.78 & 0.96 \\
Plateau & $8 \times 5$ & 56.16 & 0.94 \\
\hline
\end{tabular}




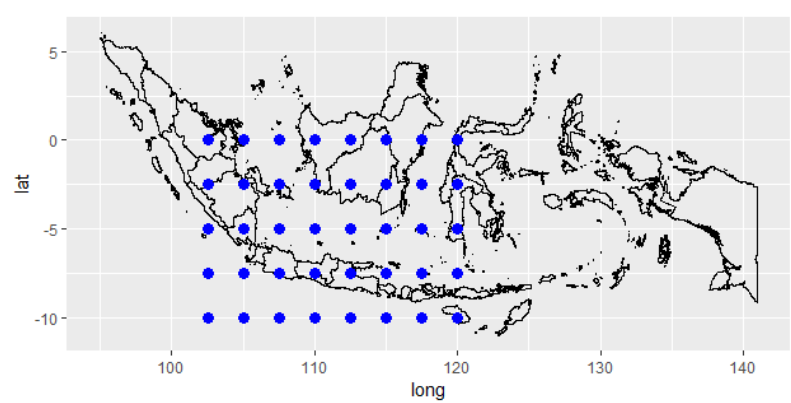

Fig. 4. The optimum GCM domain for West Java

\section{Conclusion}

Based on the results, it could be concluded that the optimum GCM domain for West Java is $8 \times 5$. This domain could improve the accuracy of monthly rainfall prediction compared to previous studies. The method of determining the GCM domain in this study also could be applied to other regions of Indonesia.

\section{References}

[1] BMKG [Badan Meteorologi, Klimatologi, dan Geofisika] : BMKG: Tren Hujan Terus Meningkat : $\quad$ https://jabarprov.go.id/index.php/news/20028/2016/11/16/BMKG-Trend-Curah-Hujan-TerusMeningkat. (2019)

[2] BMKG [Badan Meteorologi, Klimatologi, dan Geofisika] : Potensi Kekeringan Meteorologis di Beberapa Wilayah di Indonesia. : https://www.bmkg.go.id/press-release/?p=potensi-kekeringanmeteorologis-di-beberapa-wilayah-di-indonesia\&tag=\&lang=ID (2019)

[3] Busuioc, A., Chen, D., Hellstro, C. : Performance of Statistical Downscaling Models in GCM Validation and Regional Climate Change Estimates: Application for Swedish Precipitation. International Journal of Climatology. 21 557-578 (2001)
[4] Garcia ,E. : A Tutorial on Correlation Coefficients. https://pdfs.semanticscholar.org/c3e1/095209d3f72ff66e07b8f3b152fab099edea.pdf. (2019)

[5] Marpaung, S. : PengaruhTopografiterhadap Curah HujanMusimandanTahunan di Provinsi Bali Berdasarkan Data ObservasiResolusi Tinggi. Prosiding Seminar PenerbangandanAntariksa. 104-110 (2010)

[6] Nuryanto, B., Priyatmojo, A., Hadisutrisno,B. :Pengaruh Tinggi TempatdanTipeTanamanPaditerhadapKeparahanPenyakitHawarPelepah :Jurnal Penelitian Pertanian Tanaman Pangan 33(1) 1. doi:10.21082/jpptp.v33n1.2014.p1-8 (2018)

[7] Santri, D. :Pemodelan Statistical Downscaling denganRegresiKuantilMenggunakan LASSO untukPendugaan Curah HujanEkstrim. Bogor (ID): Institut Pertanian Bogor(2016)

[8] Wigena, A.H.: Pemodelan Statistical Downscaling DenganRegresi Projection Pursuit UntukPeramalan Curah HujanBulanan (Kasus Curah hujanbulanan di Indramayu). Bogor (ID): Institut Pertanian Bogor (2006)

[9] Wilby, R.L., Wigley, T.M.L.: Precipitation predictors for downscaling: Observed and general circulation model relationships. International Journal of Climatology. 20(6) 641-661. doi:10.1002/(SICI)1097-0088(200005)20:6<641::AID-JOC501>3.0.CO;2-1 (2000)

[10]Zorita, E., Von Storch, H.: The Analog Method as a Simple Statistical Downscaling Technique : Comparison with More Complicated Methods. Journal of Climate. 2474-2489. doi:10.1175/15200442(1999)012<2474:TAMAAS > 2.0.CO;2 (1999) 